\title{
$9 \quad$ Living with water in the Tøndermarsk and Gotteskoog
}

\author{
Anne Marie Overgaard
}

\begin{abstract}
The incorporation of Northern Schleswig into Denmark (1920) paved the way for the draining of the reclaimed marshes of the Tøndermarsk and Gotteskoog, as peripheral areas suddenly gained political interest and hence received the necessary investments to implement the draining project on the Danish and German side in 1925-1930 and 1930-1932 respectively. The purpose was to improve the conditions for agricultural development by gaining control overover water from the geestland. And within a few years, the drainage of the Tøndermarsk and Gotteskoog changed the landscape completely, as well as the living conditions for the inhabitants there. Based in part on interviews with local inhabitants who lived in the marshes at the time of the draining, the author has tried to identify the challenges to the traditional lifestyle caused by the draining project and how the locals experienced the change of the landscape and living conditions.
\end{abstract}

Keywords: Tøndermarsk, Gotteskoog, draining, living conditions, landscape change

\section{Introduction}

There is an old German saying: 'If we do not drown in salt water, we will drown in fresh water', which refers to the amphibious nature of many reclaimed marsh areas challenged by water from the geest (the inland Pleistocene sandy soils). For centuries, much effort has been put into draining these reclaimed marsh areas. Today, however, controlled flooding behind the dikes is seen as a possible solution to future climate changes.

Egberts, Linde \& Schroor, Meindert (eds.), Waddenland Outstanding: The History, Landscape and Cultural Heritage of the Wadden Sea Region. Amsterdam: Amsterdam University Press, 2018 DOI: 10.5117/9789462986602/CHo9 
Figure 9.1 Map of the Tøndermarsk area on both sides of the Danish-German border.

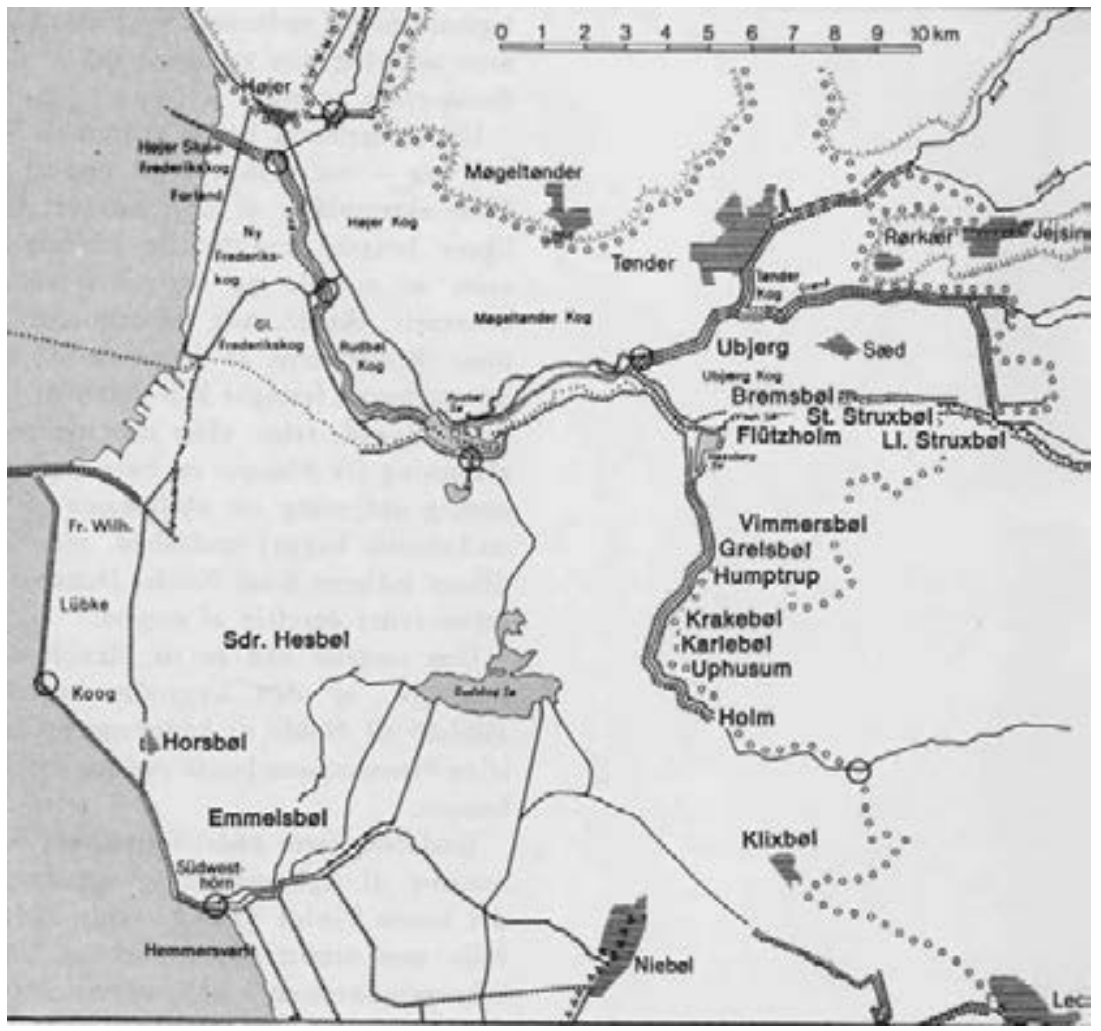

Courtesy of the Fisheries and Martime Museum, Esbjerg

The landscape of the Tøndermarsk and Gotteskoog underwent great changes following the drainage of the marshes between 1927 and $193^{2}$ (1927-30 on the Danish side and 1930-32 on the German side). A complex system of piping, drainage and irrigation ditches, dikes on the shores of the river Vidå and pumping stations changed the amphibious landscape for good. Daily life in the Tøndermarsk and Gotteskoog was also transformed, because it had been very much adapted to the natural environment; in other words, it had reconciled itself to the presence of water.

From 1968 to 1971, the Fisheries and Maritime Museum in Esbjerg researched the marsh areas of Western Schleswig with the objective of gaining knowledge about the traditional types of boats used in the area as well as the life of the smallholder, who might have held several supplementary occupations. The project resulted in a book called Boats and boatmen in the marsh 
('Både og bådfolk i marsken'). The research included about 45 interviews with people who had experienced the landscape of the Tøndermarsk and Gotteskoog before they had been drained. Though the research focuses on the topic of boats, boatmen and smallholders, the material also contains information about living conditions in general, challenges to everyday life, the experiences of the draining, and the changing of the landscape. With the help of interviews as well as photos recorded by local photographers of the marsh before and after the draining, one can begin to understand the significance of the presence of water for the local community.

\section{Description of the area}

The Tøndermarsk is a reclaimed marsh landscape that covers areas in both Denmark and Germany. In Denmark, it covers 85 square kilometres of reclaimed land from the village of Sæd south of Tønder town and 17 kilometres westward to the Wadden Sea. On the German side, the marsh stretches about 20 kilometres to the south. Gotteskoog is one of the polders south of the Danish-German border.

The natural landscape is characterised by several lakes and streams, which before the drainage formed a delta around the Vidå river. This landscape is also the most northern polder marsh in the Wadden Sea, and the only one of its kind in Denmark. The area that is the focus of this article is the marsh south of the village of Højer and on the German side the Gotteskoog.

The first sea dike was built here in the fifteenth century, as the 'golden ring' closed around Wieding Harde. The dike of Duke Hans the Elder from Højer to Rudbøl was built in 1556, and just ten years later the Gotteskoog was reclaimed. After that, several land reclamations were made. In the 1920 s 'the golden ring' around Wieding Harde and the Højer Dyke from 1861 constituted the sea dike protection to the west of the marshes in Western Schleswig.

However, the greatest challenge for the people living in the marsh was the geest water coming from the east combined with the increasing difficulty of leading the water into the Wadden Sea due to the land reclamations of the eighteenth and nineteenth centuries. This was particularly challenging in the Gotteskoog, because large parts of the polder were lower than the neighbouring more recent polders, and were therefore covered with water for most of the year. Moreover, the polders north of the Gotteskoog (Højer Kog, Rudbøl Kog and Møgeltønder Kog) faced the additional problem of fresh water flooding several months a year. 
Many attempts were made to solve the problem: several canals were dug to lead the water around and away from the lower areas, and in some places windmills equipped with an Archimedean screw to lift the water were employed. In the long run, however, all of these efforts proved unsuccessful.

\section{Settlement in the marsh}

The inhabitants in the marshlands settled as high as possible to avoid the returning floods of the Wadden Sea. The town of Tønder and the villages of Møgeltønder and Højer were founded on the geest, while in the low marsh areas people settled on man-made mounds often placed close to the natural streams or on dikes, as in the case of the settlements of Nørremølle and Rudbøl.

The mounds were established during the time that the marshlands had no high sea dikes protecting the area from the floods during winter storms. During periods with high water levels, the mounds looked like small islands surrounded by water. After the establishment of high sea dikes, the low marshland was challenged not by floods of salt water from the Wadden Sea but by fresh water from the streams running through the marshlands from the east. The natural passage of geest water was now blocked when the sluices on the coast closed for longer periods of time due to high water levels in the sea. Hence mounds continued to be important even after the marshland was protected by a dike.

\section{Water as infrastructure}

During the long fresh-water winter floods, the marshlands were practically inaccessible for ordinary means of traffic. Access to the marshlands was challenging at all times, as there were only a few roads and they were often in a poor state. This is one of the reasons why the mounds were placed near lakes, natural streams and tideways, making water a central part of the infrastructure.

Fisherman Theodor Andersen from the village of Aventoft said: 'In autumn [...] it was so full of mud everywhere, that for every step you took, you had to make sure your boots would follow' (FIMUS 51/1985). And the artist Emil Nolde called his horse a 'water horse', as it would cross the water fearlessly even though it could be up to one metre high (Møller 1973: 6).

Natural streams, lakes and remains of former tideways therefore formed the infrastructure of the marshlands and were supplemented 
Figure 9.2 Fresh water flooding in Møgeltønder Kog, 1913.

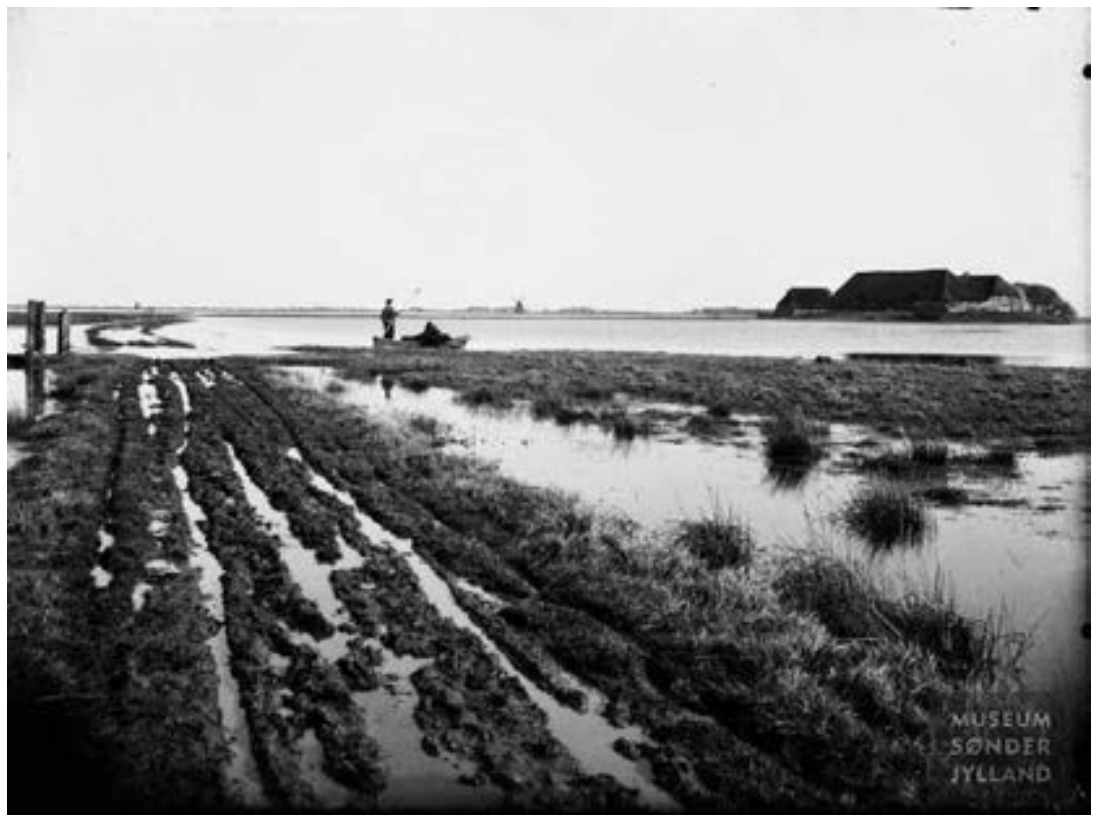

Photo by H. C. Davidsen

by man-made ditches and canals. In terms of transport, the waterways were of vital significance to the inhabitants, who often lived several kilometres from the geest. Here, they used special flat-bottomed marsh boats designed to sail on low water using poles or a simple mast and sail on more open waters.

Many ditches were not navigable and were crossed with a pole measuring 3.6o metres and featuring a transverse block that prevents it from sinking deep in the mud (the pole's local name is 'æklu'stach'). The pole was essential to the herdsman moving from one field to another looking after the grazing livestock as well as the many children who had to cross several ditches on their way to school.

In winter, ice skating was a common and important method of individual transport, when the water froze and covered the marsh with ice. This made it easier and faster to travel around, as it was possible to take short cuts, which normally would be impossible. Lorentz Petersen (1896) from Rosenkrans had never seen anyone ice skating as good as his dad, who could run 100 metres on one foot (FIMUS $56 / 1985$ ). Both pole jumping and distance skating was common behind the dikes in both the German and Dutch parts of the Wadden Sea coast. 


\section{Ways of living}

The inhabitants in the marsh often had several sources of income. One way of earning a living was transporting goods on the water, since land transport through the marshlands was not an option. As ships arriving in the Wadden Sea could not pass through the sluices to access Tønder, it became necessary for the goods transported to and from Tønder from the coast to be reloaded into smaller boats. At the beginning of the twentieth century this practice began to change due to better roads (for example from Rudbøl).

The two most fundamental and common ways of making a living were the cutting of reeds and livestock farming reliant on the hay collected and sailed home from the Gotteskoog. Even rather large farms could have their primary income from harvesting reeds on their land. Just as fields of grass were divided into parcels, the same was the case for the amphibious land with reed forests. Often, people who did not own land themselves were hired to harvest the reeds, which were sold on the geest - for example at the market in Tønder, or shipped from Højer Sluice.

Fishing was for some a primary source of income and was carried out both in the Wadden Sea as well as in streams and lakes inside the dikes. Fishing rights were sometimes linked to specific houses or farms, but often the right to fish was owned by the local government and could be rented. The fish were sold on the market in Tønder or to the hotels on Sylt or in Flensburg. Fish was an important source of food. Given that the poor did not possess any land, it was especially vital that they could fish and hence always have something to eat. They bought fishing cards, which allowed them to catch fish for their own consumption.

\section{New political attention, new possibilities}

During the 1920s, the Tøndermarsk gained political attention. In 1864, following the Danish defeat to Prussia in the Second Schleswig War, Schleswig alongside with Holstein and Lauenburg was incorporated into Prussia. After the German defeat in the First World War, national affiliation of several European borderlands — including Schleswig — was determined by referendums. The referendum held in Northern Schleswig on 10 February 1920 resulted in the incorporation of Northern Schleswig into Denmark. From a Danish perspective, Northern Schleswig had been reunited with Denmark after five decades under foreign rule. Furthermore, the region had been a part of the First World War, in contrast to the rest of Denmark. And given this background, there was much political goodwill and investments directed 
to this otherwise peripheral part of Denmark. The division of Schleswig in 1920 was significant in the marshlands south of Tønder because a natural landscape was now divided between two nations. It also meant that Tønder, Møgeltønder and Højer lost their natural catchment area.

During the nineteenth century, the problem with fresh water floods became worse in the Tøndermarsk and Gotteskoog areas due to greater amounts of water from the geest running into the marshlands, caused by draining of the geest land. The large amount of geest water created more and longer backwater flooding and challenged both the existent agricultural practices and the possibilities for further developing these practices.

The local newspaper Vestslesvigsk Tidende wrote in August 1920 that the heavy rain in the previous weeks had put the meadows south and west of Tønder under water; the owners of the meadows had suffered great losses because the livestock had to be moved from the meadows. About half of the 100 cows that delivered milk to the town had to be sold because the owners were unable to get grass or hay for their animals (Becker-Christensen 1993: 19).

Up until the reunification of Northern Schleswig with Denmark, agriculture in Western Schleswig was characterised by the fattening of livestock to be sold on the German markets via the livestock markets of Tønder and Husum. With the loss of its most important market, agriculture in Northern Schleswig had to be reoriented towards holding dairy cattle and corn production.

The Danish state invested large amounts of money in developing Northern Schleswig, and from the very beginning the marsh areas were considered to have significant agricultural potential. The decision to drain the Tøndermarsk must be seen in this context: the political will to solve the geest water issue was present, as was the technology and not the least the finances (Overgaard 2012: 109).

\section{Draining the Tøndermarsk}

The law concerning the draining of the Tøndermarsk was passed in the Danish parliament in 1925, and the work began in 1926. The Danish engineer Ulrik Petersen made the drainage plan in which electric pumps were to be the central component of the artificial draining of the marsh areas. Geest water was to be led not into but around the Tøndermarsk with the help of channels, while the water in the marsh had to be lifted up into draining ditches and from there into the Vidå river and out into the Wadden Sea. To prevent the Vidå river from flooding the marsh, dikes were established on 
both sides of the river from Tønder to Højer Sluice. That this was a prestige project was underlined by the fact that the two largest of the four pumping stations were designed by the estate manager of Schackenborg Castle in Møgeltønder, H.C. Davidsen, who was a well-known architect in the area and a representative of architecture inspired by the traditional style of building in West Schleswig.

The draining project was not popular among all people living in the marshlands, especially not among those whose previous way of living depended on the presence of water. The livelihood of several larger farms was based on harvesting reeds, and the owners were not experienced with the intensive agriculture planned after the drainage was complete. The senior supervisor in charge of the dikes in Wiedingharde, Überdeichgraf Volquardsen from Tetenböll, supported the draining but stated that it was extremely difficult for people to imagine the landscape drained. And the promises of the draining committee that draining the marsh would make 'fields of wheat' out of 'land with reeds' did not always make sense in the minds of the local inhabitants (FIMUS 54/1985).

The people who relied on the waterways to make a living through reed or hay harvesting or the transportation of goods did not themselves own land and were the hardest hit by the changes. These people were also those were dependent on the fish in the streams and lakes as a daily source of food and thus felt their existence threatened by the Tøndermarsk drainage project.

\section{Worsening water quality}

The landscape and the inhabitants were not only challenged by falling water levels, but the problems posed by the sewage from Tønder did not make the situation easier. A visitor to Tønder in 1920 would immediately notice the open sewers, which contributed to the somewhat 'rustic' atmosphere there. As the former land inspector Mosbech put it: 'Tønder maintained its distinctive character by the complete lack of sewers and wide use of open gutters.' (Mosbech 1943-44: 288) At this time, there were still many stables in the town: no less than 122 horses, 713 heads of cattle, 38 sheep and about 400 pigs still lived there (Becker-Christensen 1993: 22). The presence of this number of animals was a problem in terms of hygiene.

The mayor of Tønder, Oluf. P. Olufsen, presented this problem to members of parliament visiting Tønder in 1920, and in 1923-1925 a system of sewers was built in the town, mostly financed by the Danish state. The sewers improved both the smell and the hygiene in Tønder, but it also discharged the sewage directly into the Vidå River, thus polluting the water. Furthermore, within 
only a couple of years, the water level in the marsh fell about one metre due to the drainage project. Both of these factors had a profound impact on the quality of the drinking water. The inhabitants in the marsh got their drinking water from man-made rainwater reservoirs ('feting') or from the streams, lakes and ditches. The lower amounts of water due to the falling water level from 1927 onwards resulted in a lowered current in the water which, combined with the sewage from Tønder being discharged into the Vidå River, made the water less clear.

Lorentz Petersen (born in 1896 in Rosenkrans) describes the water in Rudbøl Lake after the drainage as 'pumped dirt' as opposed to the 'clean stream water' of former times (FIMUS 56/1985). And to Emil Nolde, who was very much against the drainage project, the water situation in the end became his reason to leave his home on the mound of Utenwarft. As Nolde formulated it: "The worst situation arose as the sewers of Tønder were discharged into the Vidå River and the desperate protests from us and all of those who lived by the Vidå River were ignored. Then we could not stay any longer.' (Nolde 2011: 410).

\section{One landscape - two nations}

Until the division of Schleswig (1920), all marsh areas in Tønder County were organised under the First Dike Confederation of Schleswig, with the common administration of dikes and draining as well as a common dike supervisor. In 1922, a Danish-German Federation of Border Streams was set up, tasked with making decisions regarding issues in relation to the water level in the streams along the border, including the regulation and maintenance of streams and dikes in the Tøndermarsk.

The reunification of Northern Schleswig with Denmark posed serious challenges to the Gotteskoog because most of the water from the Gotteskoog was led out of the polder through the Vidå River, now in Denmark. The solution in Gotteskoog was also the establishment of pumping stations, which brought an end to many years of natural drainage. The new pumping stations on the Danish side of the border increased the amount of water in the Vidå River so much that large areas south of the border were flooded. The result of the flooding was the construction of the Verlath pumping station near Rudbøl Lake that would ensure the continued draining of water from Gotteskoog (Gottburgsen \& Hassenpflug 1991: 99). In addition to the pumping station near Rudbøl Lake, the building of a further pumping station, the Hemenswarf near Südwesthörn, ensured the draining of the southern part of Gotteskoog. 
Figure 9.3 Building one of the pumping stations in 1928-29 in the Tøndermarsk

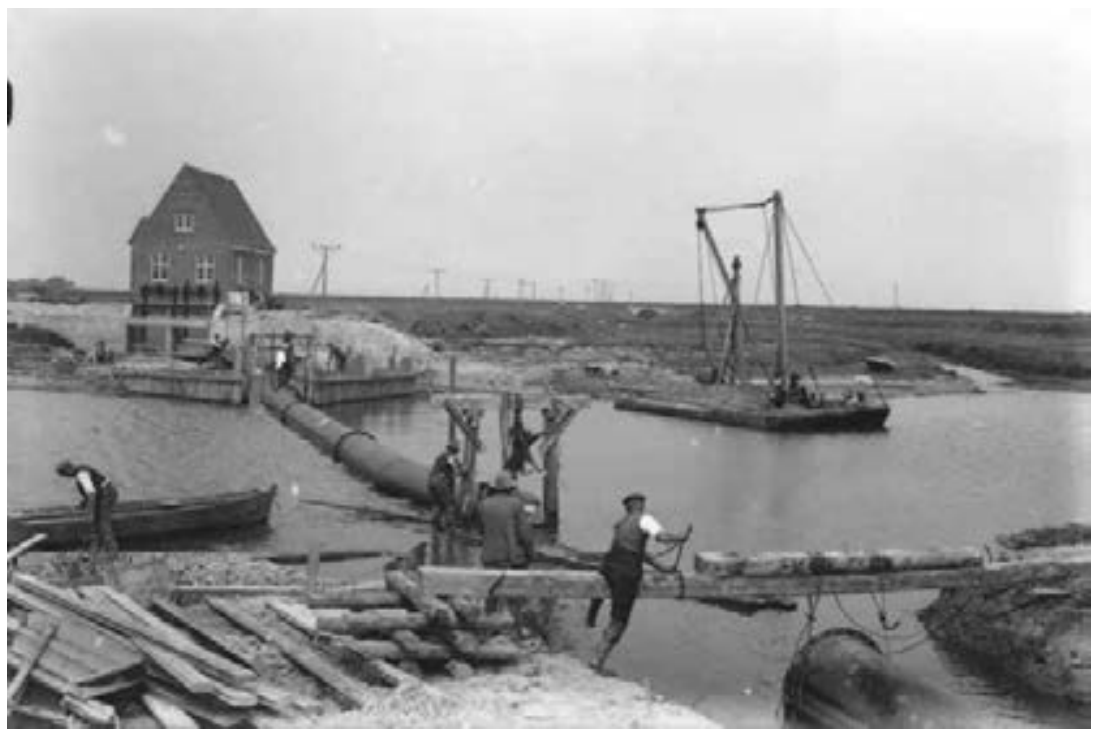

Photo by A. Martinsen

\section{Defenders of the landscape}

There were many who were critical of the drainage project, as it was not only a question of what was to be gained by the project but also what would be lost. One famous opponent was the artist Emil Nolde, who grew up by the shores of the Vidå River and lived in the marsh for many years — first at Utenwarf for ten years and later at Seebüll.

Nolde produced an alternative proposal to the drainage project made by Ulrik Petersen, which was sent to the drainage committee. The proposal involved reclaiming new land west of Højer Sluice and using parts of the new polder as a water reservoir. According to Nolde, no dikes along the Vidå River or pumping stations would be necessary. The water level would be lowered, but the method of draining would be less damaging to the character of the landscape (Eller 2011: 26).

Nolde's proposal was supported by the Danish Society for Nature Conservation, whose president, Erick Struckmann (1875-1962), addressed an audience in Tønder the same year, where he pleaded with them to protect the nature, arguing that it was so well preserved (Wesenberg-Lund 1925-26: 40).

Carl Wesenberg-Lund (1867-1955), a professor with a speciality in fresh water fauna, was present at the discussion between Erick Struckmann 
and Ulrik Pedersen and recognised the wish to develop the Tøndermarsk for economic reasons. But he also stated: 'On the other side [...] to us, who with fresh eyes, for the first time sees the wonderful landscapes of the Tøndermarsk, it is clear that if there is any Danish landscape in danger of having its scenic beauty destroyed, it is precisely, because of its grand uniformity, the landscape of the marsh.' (Wesenberg-Lund 1925-26: 43).

\section{The landscape in the eyes of the inhabitants}

The interviews conducted by the Fisheries and Maritime Museum in Esbjerg reveal how the inhabitants of the marsh experienced the landscape after it was drained. The attitudes towards the new marsh landscape and the changes made to it seem to have been diverse.

Boatman Boy Jacobsen, who was born 1880 in Neukirchen, said: 'In 1932, as the draining was fully implemented, everyone thought that it was very bad for "the working people" now there were no reeds anymore. Everything developed differently though and the drained marsh land, before the draining was covered with reeds, is now the best "plough land"' (FIMUS 59/1985). Although it would appear that Jacobsen considered this a good thing; however, later he commented: 'This region was much more beautiful before the draining, one saw everywhere reeds surrounded by water, overgrown with duckweed, waterlilies and other kinds of water plants. Early in the morning, when one took the boat to Gotteskoog, everything came so much alive as the sun rose, all kinds of birds were heard.' Thomas Petersen from Neukirchen noted that, as far as he knew, most inhabitants in the marshes would rather have kept the life conditions from before the draining (FIMUS 53/1985).

\section{Concluding remarks}

After years of trying to solve the challenge of backwater flooding in the Tøndermarsk, it was a national event - the incorporation of Northern Schleswig with Denmark - that paved the way for the drainage, in combination with technological developments and the belief that nature could be controlled.

The drainage of the Tøndermarsk and Gotteskoog changed not only the landscape but also the living conditions for the inhabitants there, especially in the areas around Rudbøl Lake and Gotteskoog where a lifestyle that had adapted to the presence of water was challenged by falling water levels in 
the streams and lakes. People were forced to get used to a different way of life and doing things differently, and for some it meant the knowledge and know-how they had inherited and to some extent developed became irrelevant.

Furthermore, the local inhabitants were also greatly affected by problems posed with regards to the access to clean drinking water, caused in part by the sewage systems in the town of Tønder. The change of the landscape was experienced differently by the locals, and the experiences were to some extent full of contradictions: some were surprised at how well-suited the marsh became for agriculture, though at the same time they lamented the absence of birds and water plants.

\section{References}

The Fisheries and Maritime Museum in Esbjerg (FIMUS): The Tøndermarsk Projekt, interviews and correspondence with people in the Tøndermarsk and Gotteskoog 1968-1970

Becker-Christensen, H. (1993). Byen ved grcensen. Tønder 1920-1970. Aabenraa: Institut for Grænseregionsforskning.

Eller, S. (2011). 'Indgreb i marsklandets sjældne og særegne skønhed'. Diskussionen om afvanding og naturfredning i Tøndermarsken 1925. Sønderjyske Årbøger. Odder: Historisk Samfund for Sønderjylland. 9-44.

Gottburgsen, M \& Hassenpflug, W. (1991). Der Gotteskoog. Landschaft und Bewohner im Wandel der Jahrhunderte. Leck: K. H. Bock.

Hansen, L. (2014). Marsken ved Tønder. Digebygning og afvanding. Tønder: Lorens Hansen.

Mosbech, J. L. (1943-44). Tønder 1920-43. In Mackeprang, M. (Ed.),Tønder gennem tiderne (pp. 235-86). Tønder: Gyldendal.

Møller, A. (1973). Både og bådfolk i marsken. Esbjerg: Fiskeri- og Søfartsmuseet i Esbjerg.

Nolde, E.l (2011). Mein Leben. Freiburg: Dumont.

Overgaard, A. M. (2012). Byggeriet af Rømødæmningen. Et spørgsmål om landvinding, beskæftigelse og national handling. In Sønderjyske Årbøger 2012 (pp. 105-30). Odder: Historisk Samfund for Sønderjylland.

Wesenberg-Lund, C. (1925-26). En henstilling til Overvejelse i Anledning af de store Afvandingsprojekter. Sønderjysk Maanedsskrift 1926 (2), 40-3. 


\section{About the author}

Anne Marie Overgaard holds an master's degree in history and German from the University of Southern Denmark in Odense. Since 2008 she has been curator at the Museum of Southern Denmark (Museum Sønderjylland), where she works on the cultural history of the Wadden Sea. Her special interests are the reclaimed marsh areas and the development of early tourism on the islands of Fanø and Rømø. Additionally, she has done research regarding the traditional food culture of the Danish Wadden Sea area and how this heritage is managed by current agents of tourism. 
